\title{
Relation between Plasma Lignocaine Levels and Induced Haemodynamic Changes
}

\author{
P. F. BINNION,* M.SC., PH.D., M.R.C.P.; G. MURTAGH, $\dagger$ M.B. ; A. M. POLLOCK, $\ddagger$ M.B. ; \\ E. FLETCHER,§ M.D., F.R.C.P.
}

British Medical fournal, 1969, 3, 390-392

\begin{abstract}
Summary : Intravenous lignocaine (1 mg./kg. body $\checkmark$ weight) was found to produce insignificant haemodynamic changes, and in particular no reduction in myocardial contractility. A rate of $2 \mathrm{mg}$./minute infused intravenously is suggested for therapeutic purposes.

In anaesthetized dogs an infusion of $13.5 \mathrm{mg}$./minute caused moderate haemodynamic depression and a maximum plasma levet of $7 \mu \mathrm{g} . / \mathrm{ml}$. Massive injections of 200 and $400 \mathrm{mg}$. of lignocaine produced a maximum plasma level of 13.8 and $27.8 \mu \mathrm{g} . / \mathrm{ml}$, respectively, and in the latter failure of myocardial contraction in the presence of a normal E.C.G. ensued (" pump failure"). Lignocaine appears to alter the uptake of calcium by myocardial sarcoplasmic reticulum, and this may explain the negative inotropic effect of large doses.
\end{abstract}

\section{Introduction}

Lignocaine has become important in the management of many cardiac arrhythmias, particularly ventricular extrasystoles following myocardial infarction (Gianelly et al., 1967 ; Jewitt et al., 1968), but despite its known cardiac depressant action (negative inotropic effect) (Binnion, 1968) it appears to be safe in acute myocardial infarction (Stannard et al., 1968). When given in a dose of about $1 \mathrm{mg}$. $/ \mathrm{kg}$. intravenously as a single injection or as an infusion at a rate of $1-2 \mathrm{mg}$./minute there are no appreciable haemodynamic effects in patients (Binnion, 1968 ; Stannard et al., 1968 ; Schumacher et al., 1968) though doses of 200-400 mg. intravenously given to anaesthetized dogs (about $8-16 \mathrm{mg} . / \mathrm{kg}$.) produce a pronounced fall in myocardial contractile force and may even produce electromechanical dissociation of cardiac activity such that a normal E.C.G. is present with no myocardial contraction (Binnion, 1968).

In this paper are reported the plasma lignocaine levels determined in patients in whom the dose of drug used would cause no haemodynamic effect, and in addition the levels reached in anaesthetized dogs where the myocardial depressant effect was pronounced.

\section{Methods}

\section{Patients}

Eleven patients undergoing cardiac catheterization under light barbiturate anaesthesia with a view to surgery were investigated. Conventional catheters were used and transseptal left atrial catheterization was performed with a modified Brockenbrough needle, and where possible this catheter was placed in the left ventricle, particular care being given to the measurement of the maximum rate of rise of left ventricular pressure. Pressures were measured with Sanborn transducers $5 \mathrm{~cm}$. below

\footnotetext{
- Senior Lecturer in Physiology, Queen's University, Belfast BT9 7BL, Consultant Physiologist, Northern Ireland Hospitals Authority. IIn receipt of Research Award from the British Heart Foundation. \# Registrar in Medicine, Belfast City Hospital.

S Physician-in-charge, Cardiovascular Unit, Belfast City Hospital, Belfast BT9 17J.
}

the sternal angle. Cardiac output was measured by injecting $2.5 \mathrm{mg}$. of indocyanine green into the pulmonary artery with withdrawal of arterial blood through a Gilford 103-1R densitometer by a Gilford 105-S pump. The dye curve, pressures, and an electrocardiogram were recorded on an ultraviolet or a photographic recorder (Binnion, 1968). Haemodynamic changes are given as percentage changes from control $(\Delta \%)$.

Seven of these patients together with one after myocardial infarction had venous blood collected before and after an intravenous injection of $1 \mathrm{mg}$. of lignocaine per kilogram of body weight, given over a period of one minute. In addition in three patients a continuous infusion of lignocaine at a dosage of $1 \mathrm{mg}$./minute was started immediately after the single dose had been given, and the infusion was maintained for 60 minutes. Blood samples were collected in heparinized tubes 5, 15, 25, 35,45 , and 55 minutes after starting the infusion.

\section{Dogs}

Five dogs (weight $19 \cdot 5-36 \cdot 1 \mathrm{~kg}$.) were anaesthetized with intravenous sodium pentobarbitone ( $30 \mathrm{mg} . / \mathrm{kg}$. body weight) followed by an intramuscular injection of $60-120 \mathrm{mg}$. one hour later. An intravenous infusion of lignocaine ( $13.5 \mathrm{mg} . / \mathrm{minute})$ was given for 30 minutes, and after a delay of at least 20 minutes a rapid intravenous injection of $200 \mathrm{mg}$. and later $400 \mathrm{mg}$. of lignocaine was given. Venous blood samples were collected at appropriate intervals in heparinized tubes. In two dogs the left ventricular pressure wave was recorded by a needle introduced direct into the left ventricle and connected to a strain gauge transducer.

The human and canine blood samples were centrifuged; the plasma was removed and stored at $4^{\circ} \mathrm{C}$. until analysed. Plasma lignocaine levels were measured by gas chromatography in the laboratories of Astra A.B., Sweden.

\section{Results}

\section{Patients}

The rise in plasma lignocaine after $1 \mathrm{mg} . / \mathrm{kg}$. intravenously was not significant (Table I). The high control value $(1.76 \mu \mathrm{g} . /$

\begin{tabular}{|c|c|c|c|c|c|c|c|c|c|}
\hline \multirow{3}{*}{ Procedure } & \multirow{3}{*}{$\begin{array}{c}\text { No. } \\
\text { of } \\
\text { cases }\end{array}$} & \multicolumn{8}{|c|}{ Mean ( \pm S.E.) plasma level ( $\mu \mathrm{g} . / \mathrm{ml})}$. \\
\hline & & \multirow{2}{*}{ Control } & \multirow{2}{*}{$\begin{array}{l}\text { At end of } \\
\text { injection }\end{array}$} & \multicolumn{6}{|c|}{ Minutes after starting infusion } \\
\hline & & & & 5 & 15 & 25 & 35 & 45 & 55 \\
\hline $\begin{array}{c}1 \mathrm{mg} / \mathrm{kg} . \\
\text { bolus } \\
1 \mathrm{mg} . / \mathrm{min} . \\
\text { infusion }\end{array}$ & $\begin{array}{l}8 \\
3\end{array}$ & $1.76( \pm 0.32)$ & $1.96( \pm 0.28)$ & 1.95 & $1 \cdot 43$ & $1 \cdot 83$ & 1.63 & $1 \cdot 50$ & 1.35 \\
\hline
\end{tabular}

ml.) reflects the use of lignocaine for skin infiltration during routine catheterization, which was done more than one hour before the plasma samples were taken. There was a progressive fall in plasma lignocaine levels over the succeeding 55 minutes. The haemodynamic effects of the single injection are shown 
in Table II. There is a slight rise in heart rate but no significant change in cardiac output, and, more particularly, there is no measurable fall in left ventricular maximum $\mathrm{dp} / \mathrm{dt}$ at the end of the injection. Previous work has shown that the continuous infusion technique with the dosage used in these investigations causes no significant haemodynamic changes (Binnion, 1968), and this was confirmed again with the larger group of patients.

TABLE II.-Haemodynamic Changes Produced by a Bolus Injection of $1 \mathrm{mg}$. Lignocaine per kg. Body Weight in Patients

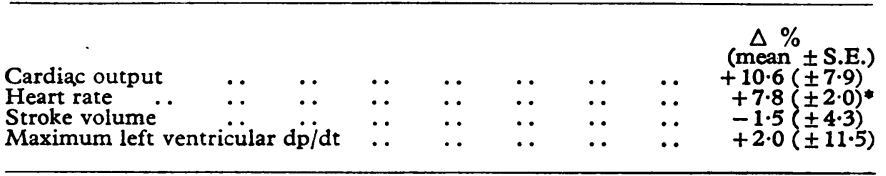

P $<0.05$.

\section{Dogs}

No lignocaine was used to infiltrate the skin and all control plasma lignocaine levels were below $0.3 \mu \mathrm{g} . / \mathrm{ml}$. (Table III). During the infusion at $13.5 \mathrm{mg}$. of lignocaine per minute there was an increase in plasma level to $7.03 \mu \mathrm{g} . / \mathrm{ml}$. after 30 minutes, and the level fell progressively over the next 20 minutes but was still raised at the end of the 20-minute period. Although the haemodynamic effects reported previously (Binnion, 1968) were essentially the same, maximum left ventricular $\mathrm{dp} / \mathrm{dt}$ fell in the two dogs by an average of $8.7 \%$, $11.1 \%$, and $21.8 \%$ respectively after 10,20 , and 30 minutes of lignocaine infusion.

TABLE III.-Plasma Lignocaine Levels $(\mu \mathrm{g} . / \mathrm{ml}$.) in Anaesthetized Dogs Infused at $13.5 \mathrm{mg}$. Lignocaine per Minute

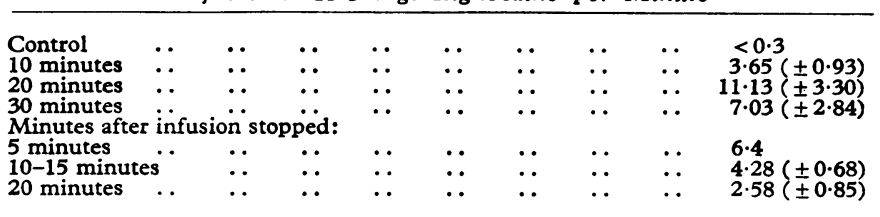

TABLE IV.-Plasma Lignocaine Levels ( $\mu \mathrm{g}_{\mathrm{g}} / \mathrm{ml}$.) in Anaesthetized Dogs Following a Rapid Intravenous Injection

\begin{tabular}{|c|c|c|c|c|c|c|}
\hline \multirow{2}{*}{ Control } & \multicolumn{6}{|c|}{ Seconds after End of Injection } \\
\hline & 15 & 30 & 60 & 120 & 300 & $600^{*}$ \\
\hline & \multicolumn{6}{|c|}{$200 \mathrm{mg}$. lignocaine intravenously } \\
\hline $3.4( \pm 0.1)$ & $\left.\right|_{( \pm 2.58)}$ & $\begin{array}{r}11.45 \\
( \pm 3.89)\end{array}$ & $\mid \begin{array}{r}13.78 \\
( \pm 6.64\end{array}$ & $\begin{array}{c}11 \cdot 1 \\
( \pm 4 \cdot 01)\end{array}$ & $\begin{array}{c}8.45 \\
( \pm 1.99)\end{array}$ & $\begin{array}{c}4.08 \\
( \pm 1.09)\end{array}$ \\
\hline $2.70( \pm 0.58)$ & $\mid \begin{array}{c}17.52 \\
( \pm 6.59)\end{array}$ & $\begin{array}{r}400 \\
22 \cdot 3\end{array}$ & $\begin{array}{r}\text { mg. lignoc } \\
\mid \begin{array}{r}27.82 \\
( \pm 8.83\end{array}\end{array}$ & $\begin{array}{c}\text { intraven } \\
16.67 \\
( \pm 3.08)\end{array}$ & $\begin{array}{l}\text { sly } \\
( \pm .56 \\
( \pm 7.22)\end{array}$ & 10.9 \\
\hline
\end{tabular}

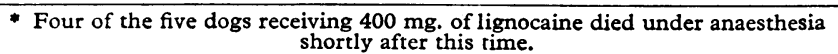

dogs recovered from this dose, after a 400-mg. injection of intravenous lignocaine, when the plasma level rose to an average maximum of $27.8 \mu \mathrm{g} . / \mathrm{ml}$. four out of the five dogs died. They did not die when the maximum level of plasma lignocaine occurred but at least several minutes loter, and the negative inotropic action did not coincide with maximum plasma levels-that is, there was not a close temporal relation between the magnitude of the negative inotropic action and plasma lignocaine levels. In two dogs where maximum left ventricular $\mathrm{dp} / \mathrm{dt}$ was measured the average change in this value after the bolus injection of 200 or $400 \mathrm{mg}$. of lignocaine is given in Fig. 1. In Fig. 2 an example of "pump failure" or electromechanical dissociation of cardiac activity is shown.

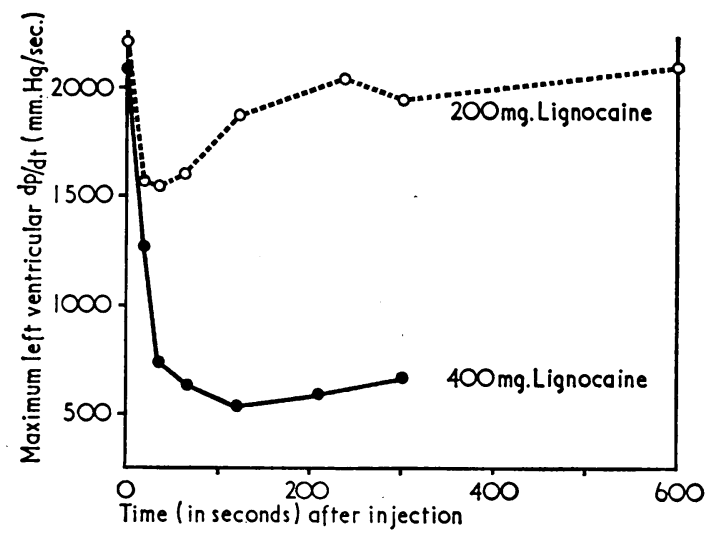

FIG. 1.-Transient effect of $200 \mathrm{mg}$. and $400 \mathrm{mg}$. of lignocaine intravenously on myocardial contractility.

\section{Discussion}

Further evidence is presented that the haemodynamic effects of an injection of lignocaine in a dose of $1 \mathrm{mg}$. $/ \mathrm{kg}$. body weight given intravenously to patients are insignificant, and even a sensitive measure of myocardial contractile forcenamely, maximum rate of rise of left ventricular pressure-is unchanged even though lignocaine has a known myocardial depressant action. There was no obvious rise in plasma lignocaine level after this dose, though the control values were higher than those measured by Scott et al. (1968), presumably because lignocaine was used as a local anaesthetic for insertion of the catheters. During an infusion of lignocaine at $1 \mathrm{mg} . /$ minute, when no haemodynamic changes occur (Binnion, 1968), the level of plasma lignocaine actually falls from its previously rather high level, which suggests that this rate of infusion is rather low if a satisfactory plasma level is to be achieved. Possibly a rate of $2 \mathrm{mg}$./minute would be more appropriate if the plasma level is to be kept within a therapeutic range of about $2 \mu \mathrm{g} . / \mathrm{ml}$. plasma.
The control value for plasma lignocaine before the $200 \mathrm{mg}$. injection was raised as the 20 -minute level arbitrarily taken between experiments was not long enough to allow the plasma lignocaine level to fall to the basal measured level of $<0.3 \mu \mathrm{g}$./ ml. (Table IV). The maximum level recorded was 13.78 $\mu \mathrm{g} . / \mathrm{ml}$. plasma 60 seconds after the end of the injection, which was long enough to permit mixing, but it had not fallen to the basal level 10 minutes later. Although all

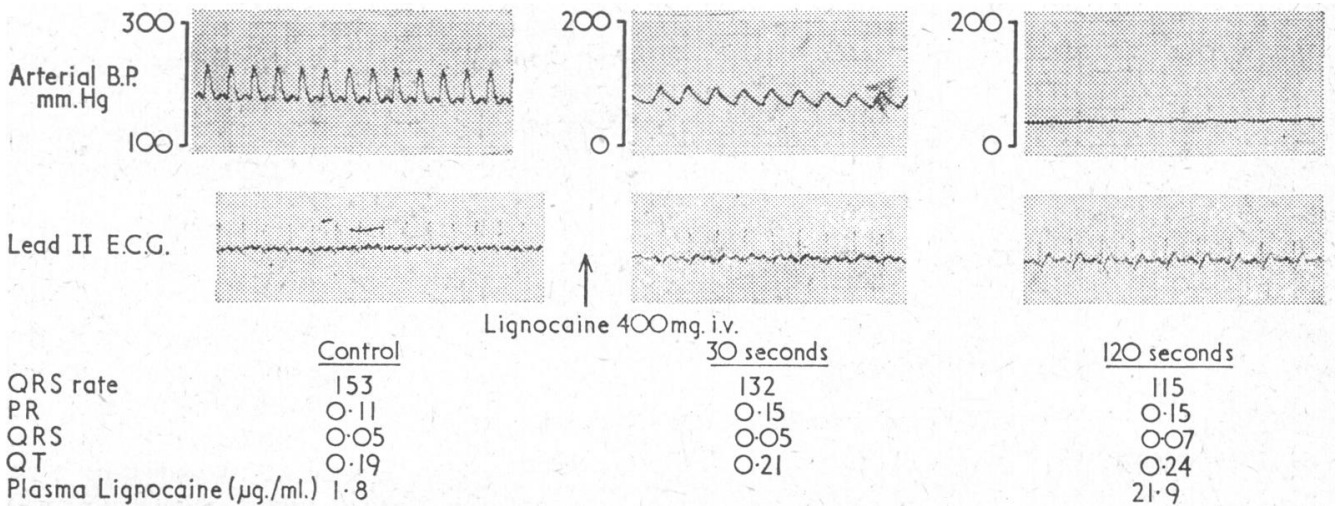

Fig. 2.-Effect of $400 \mathrm{mg}$. of lignocaine intravenously on simultaneous arterial blood pressure and E.C.G. 
Larger intravenous infusions $(13.5 \mathrm{mg}$. of lignocaine per minute) given to anaesthetized dogs produced a plasma level of $7 \mu \mathrm{g} . / \mathrm{ml}$. after $30 \mathrm{minutes,}$ though the depressant effect of such a procedure on haemodynamics was only moderate and all animals recovered satisfactorily. This probably represents the safe maximum level which might be produced in patients and agrees with the work of Scott et al. (1968). A rapid injection of $200 \mathrm{mg}$. of lignocaine produced a maximum plasma level of $13.8 \mu \mathrm{g} . / \mathrm{ml}$, and this was associated with a pronounced decrease in myocardial contractile force, and if the amount given was doubled a maximum plasma level of $27.8 \mu \mathrm{g} . / \mathrm{ml}$. was achieved with such severe diminution of myocardial contraction that death usually ensued. Death was due to failure of the heart as a pump, though electrical activity proceeded fairly normally. Dissociation of the electrical and mechanical activity of the heart has also been reported to occur when the calcium/potassium interrelations have been upset experimentally (Lee et al., 1966). This implies that lignocaine in toxic amounts interferes with the process of contraction of the cardiac muscle, and preliminary work suggests that this may be due to interference with calcium uptake by the sarcoplasmic reticulum (Baird and Binnion, unreported observations). Certainly substances such as adrenaline and isopren- aline increase calcium uptake by the sarcoplasmic reticulum and have a positive inotropic action, whereas lignocaine and other myocardial depressants like sodium pentobarbitone (Lain et al., 1968) reduce calcium uptake. It is the release of this calcium from the sarcoplasmic reticulum which causes the actin-myosin interaction and consequent muscle contraction.

We thank Astra A.B., Sweden, and especially Dr. B. Ortengren, for the lignocaine estimations,

Requests for reprints should be addressed to P. F. Binnion.

\section{REFERENCES}

Binnion, P. F. (1968). British Medical fournal, 2, 470.

Gianelly, R., Van Der Groeben, J. O., Spivack, A. P., and Harrison, D. C. (1967). New England fournal of Medicine, 277, 1215.

Jewitt, D. E., Kishon, Y., and Thomas, M. (1968). Lancet, 1, 266.

Lain, R. F., Hess, M.' L., Gertz, E. W., and Briggs, F. N. (1968). Circulation Research, 23, 597.

Lee, Y. C. P., Richman, H. G., and Visscher, M. B. (1966). American fournal of Physiology, 210, 499.

Schumacher, R. R. Lieberson, A. D., Childress, R. H., and Williams, J. F. (1968). Circulation, 37, 965.,

Scott, D. B., Jebson, P. J., Vellani, C. W., and Julian, D. G. (1968). Lancet, 2, 1209.

Stannard, M., Sloman, G., and Sangster, L. (1968). British Medical Fournal, 2, 468.

\title{
Thyroid Function in Addison's Disease
}

\author{
M. N. MAISEY,* M.B., B.SC., M.R.C.P. ; M. H. LESSOF, $†$ M.A., M.D., F.R.C.P.
}

\begin{abstract}
Summary : Clinical evidence of a thyroid disorder was present in 10 out of $\mathbf{4 0}$ patients with Addison's disease. Though the remaining 30 patients had no clinical evidence of thyroid disease, six (out of 15 tested) had thyroid microsomal antibodies and a considerably impaired response to thyrotrophin. These changes are interpreted as very early indications of developing thyroid failure. When circulating microsomal antibodies are found this seems to indicate the presence of established thyroid disease.
\end{abstract}

\section{Introduction}

The clinical association between Addison's disease of the idiopathic type and various thyroid disorders is well established (Falta, 1912 ; Schmidt, 1926 ; Carpenter et al., 1964). Schmidt (1926) found lymphocytic infiltration in the thyroid gland at necropsy in two cases of Addison's disease and postulated that this type of change might eventually lead to hypothyroidism. Irvine (1968) studied 46 patients with idiopathic Addison's disease and found thyroid abnormalities in nine and thyroid microsomal antibodies in 21 . Nevertheless, the clinical significance of the finding of antithyroid antibodies remains uncertain.

\section{Methods}

The study began with 40 patients who had Addison's disease, which was regarded as idiopathic, since there was no evidence

* Endocrine Registrar, Guy's Hospital, London S.E.1.

t Physician, Guy's Hospital, London S.E.1. of tuberculosis or of any other specific cause. Ten also showed clinical evidence of thyroid disease-two had myxoedema, five thyrotoxicosis, one a nodular goitre, one Hashimoto's disease, and one thyroiditis. Fifteen of the remaining 30 patients who did not have clinical evidence of thyroid disease agreed to attend for further investigation of their thyroid function. These investigations included fluorescent autoantibody tests carried out by applying serum to sections of various snapfrozen tissues and then staining for deposited globulin. An estimation of the serum protein-bound iodine level was also included, and so was a four-hour ${ }^{132} \mathrm{I}$ thyroid uptake test carried out both before and 18 to 24 hours after stimulation with a single intramuscular injection of 2.5 units of thyrotrophin (Thytropar). This last was regarded as a test of thyroid reserve (Hobbs et,al., 1963). Five patients who had Addison's disease of tuberculous origin were assessed in the same way, the results being compared with those found in 17 control subjects between the age of 15 and 59 years who had had thyrotrophin stimulation tests but did not show any evidence of either thyroid or adrenal disease.

\section{Results}

The details of the patients and results of the tests are shown in the Table. The cause of the Addison's disease was attributed to tuberculosis if calcification was present in the adrenal area (all five cases). Evidence of active tuberculosis was present elsewhere in two of these five cases. The remaining 15 patients were regarded as having idiopathic Addison's disease. Cinculating autoantibodies directed against the adrenal cortex were not 